\title{
Psychiatric Genetics: Methods, Findings and Ethical Issues
}

\section{Kenneth S. Kendler, MD}

Virginia Institute of Psychiatric and Behavioral Genetics

Virginia Commonwealth University

Stanford, California

June 6, 2006 



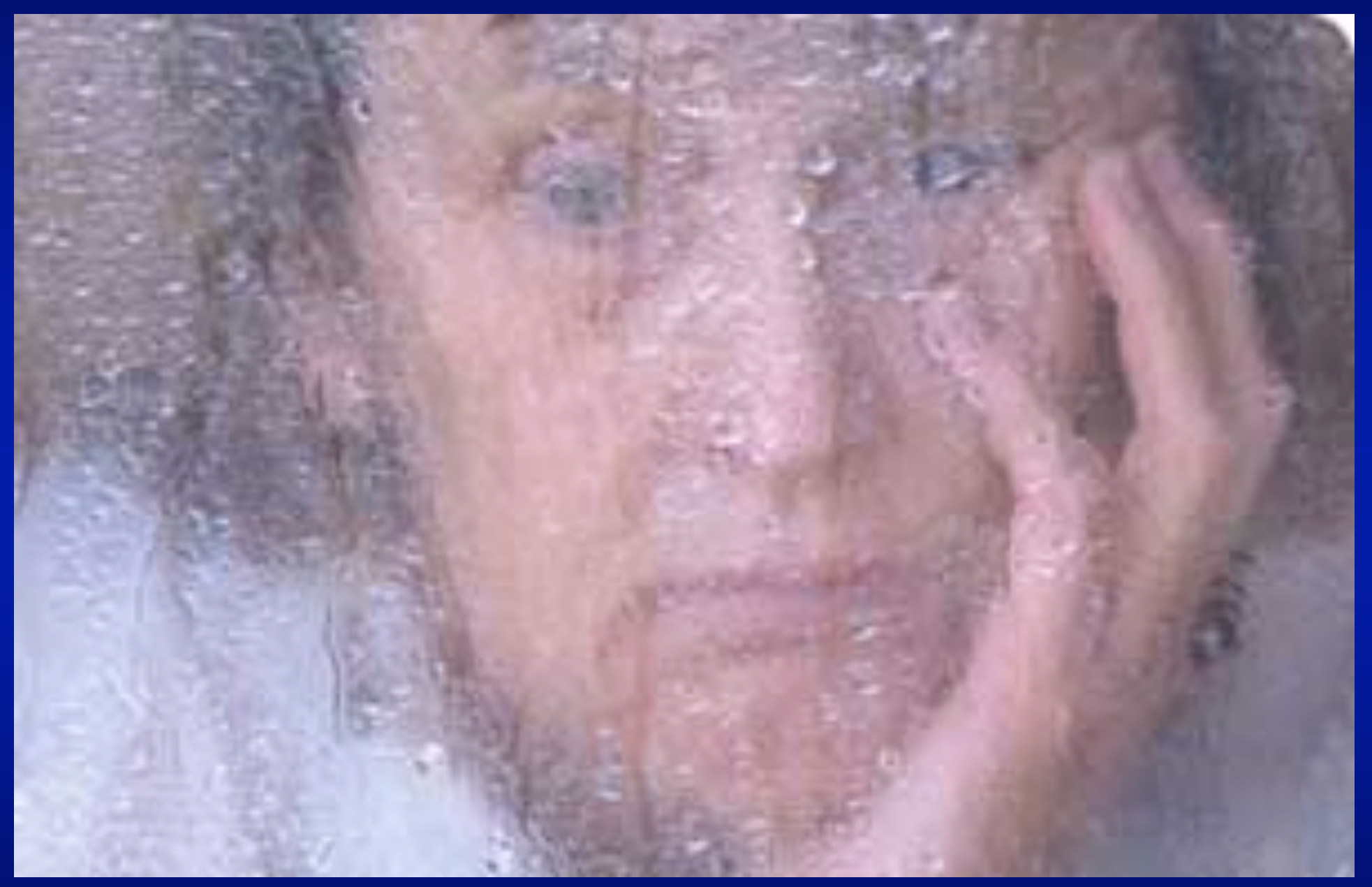




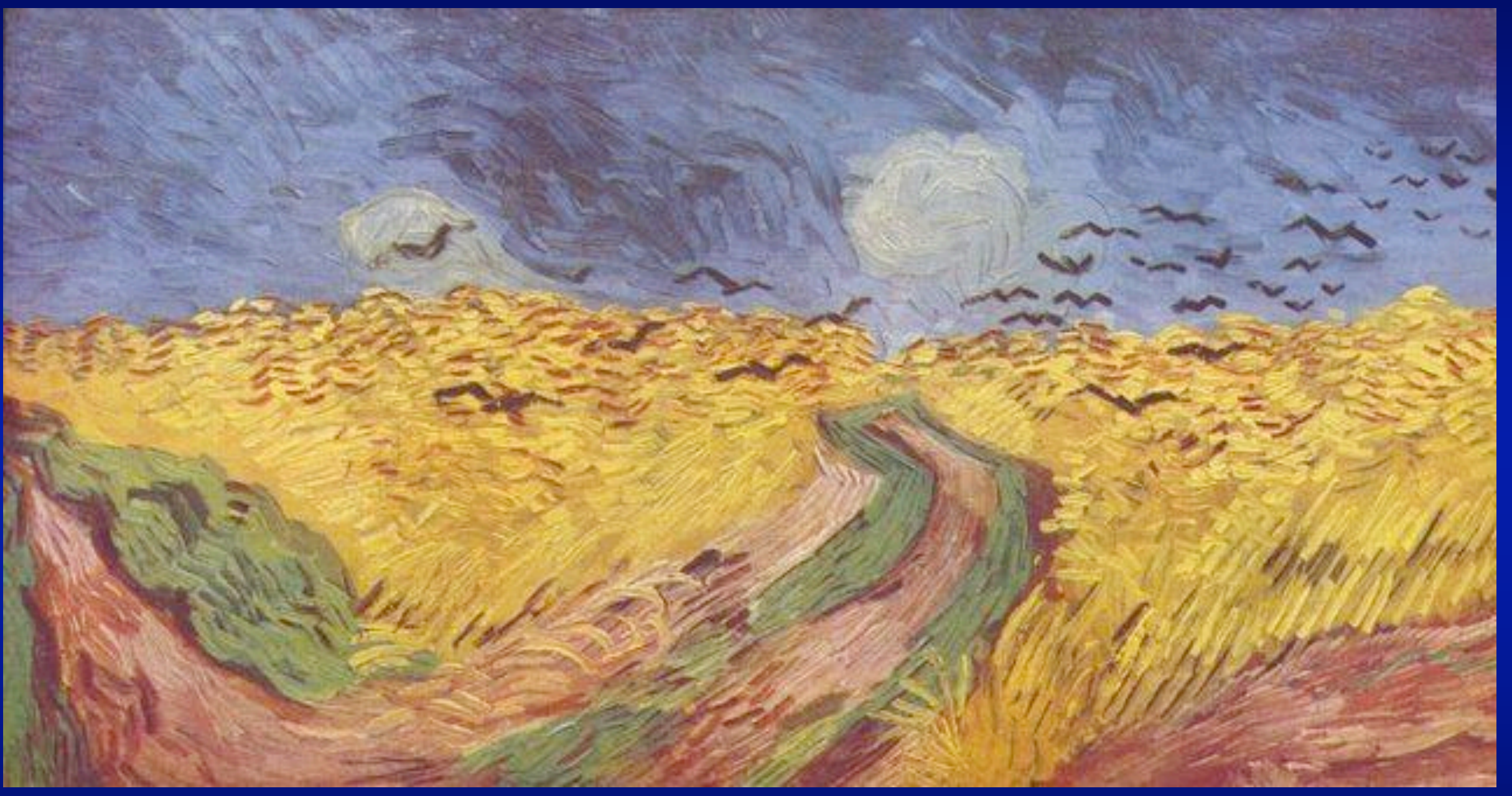




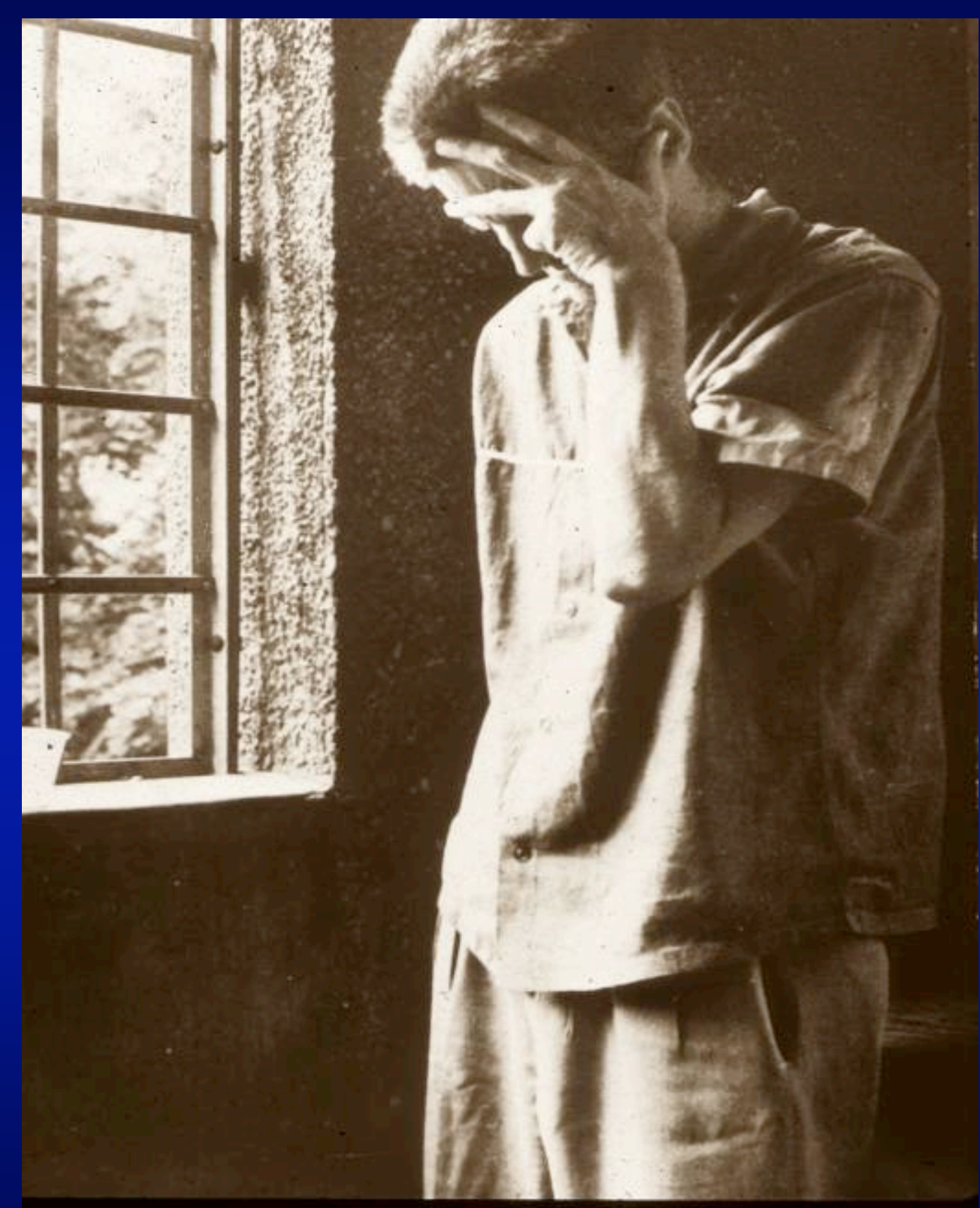




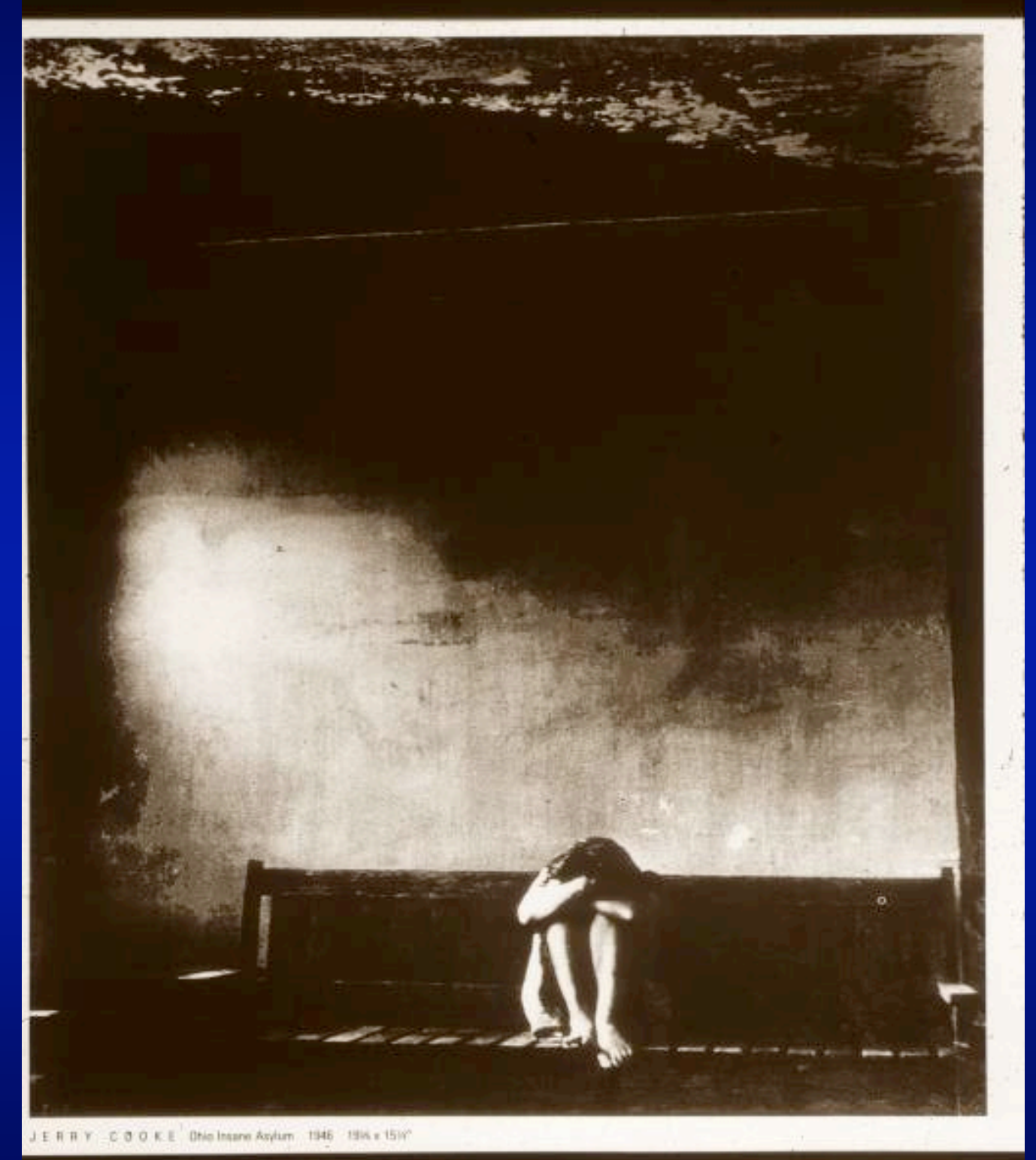




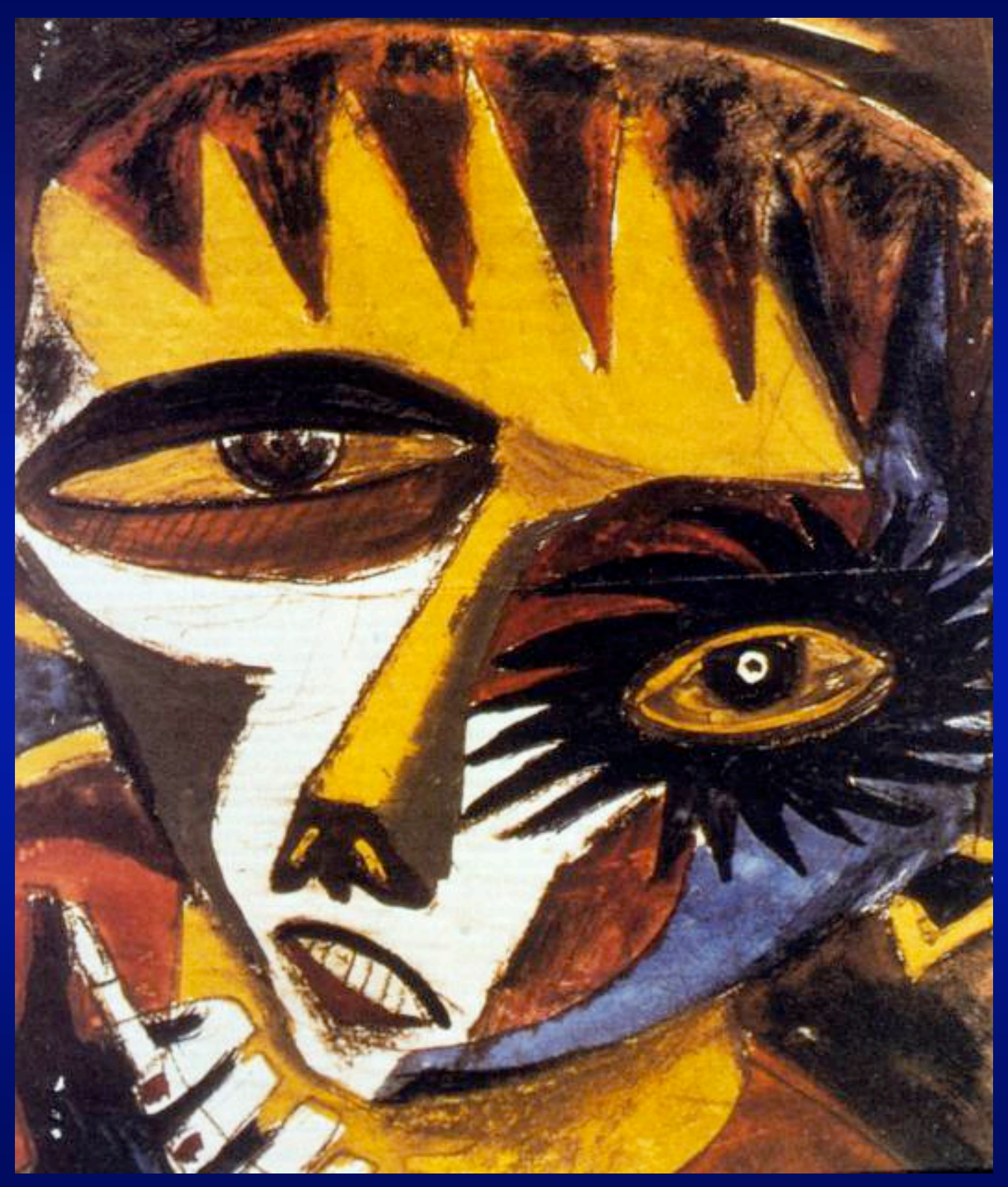




\section{Outline of Talk}

- What makes for a complex trait?

- 4 Paradigms of Psychiatric Genetics

- The broad pattern of empirical findings from the field.

- A selection of "bioethical" issues 


\section{What Makes a Human Trait "Complex" from a Genetic Perspective?}

- Three major features:

- First, the impact of individual genes on risk is small (although the cumulative effect of all genes may be rather large).

- Second, multiple aspects of the environment is also of etiologic importance.

- Third, the pathway from causes to illness is complicated. Genes and environment often don't simply add together. They may correlate. All this happens over developmental time. 


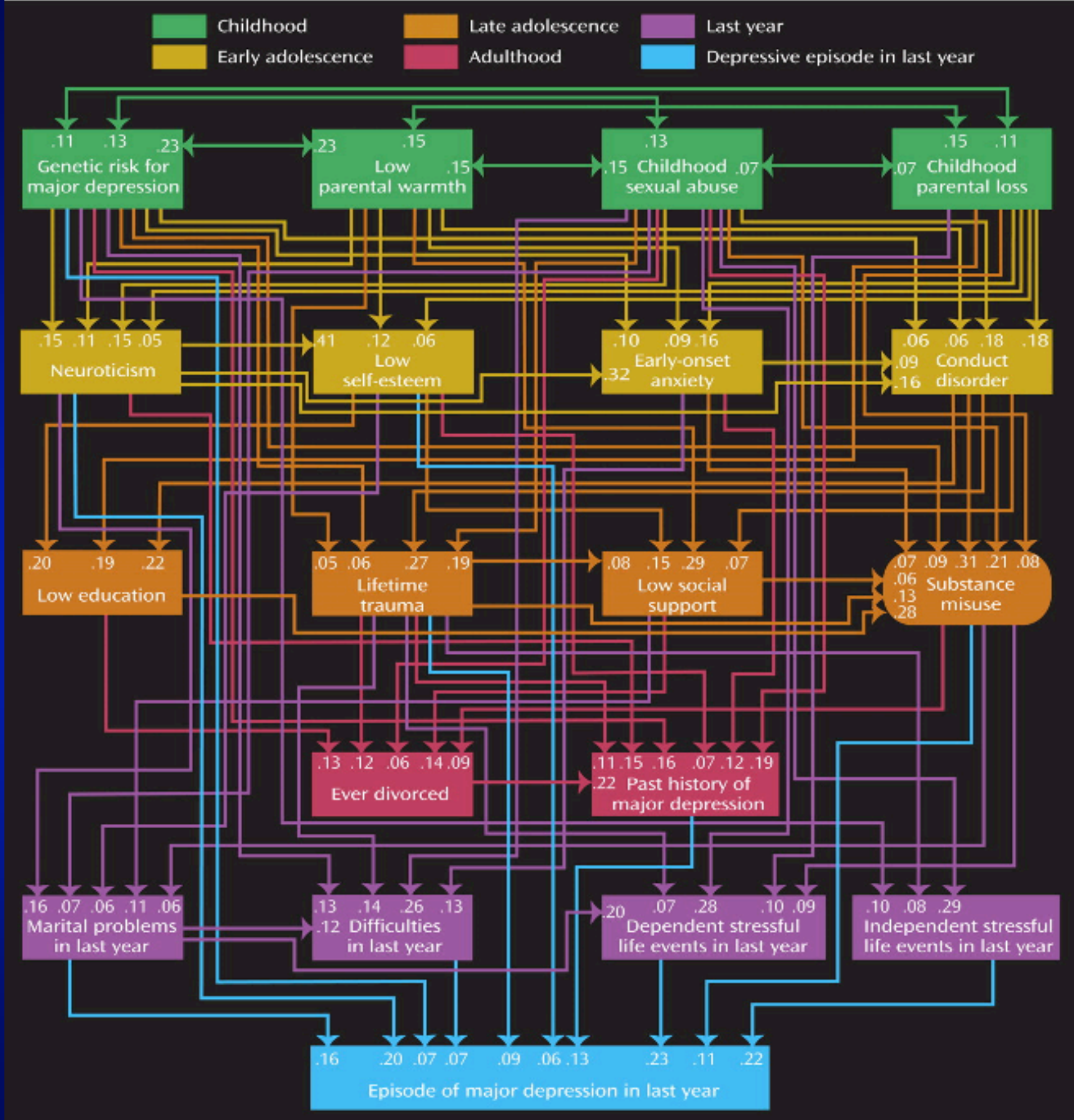




\section{TABLE 1. Four Major Paradigms of Psychiatric Genetics}

\begin{tabular}{|c|c|c|c|}
\hline Paradigm & $\begin{array}{l}\text { Samples } \\
\text { Studied }\end{array}$ & $\begin{array}{l}\text { Method } \\
\text { of Inquiry }\end{array}$ & Scientific Goals \\
\hline $\begin{array}{l}\text { 1. Basic genetic } \\
\text { epidemiology }\end{array}$ & $\begin{array}{l}\text { Family, twin, } \\
\text { and adoption } \\
\text { studies }\end{array}$ & Statistical & $\begin{array}{l}\text { To quantify the } \\
\text { degree of familial } \\
\text { aggregation and/or } \\
\text { heritability }\end{array}$ \\
\hline $\begin{array}{l}\text { 2. Advanced } \\
\text { genetic } \\
\text { epidemiology }\end{array}$ & $\begin{array}{l}\text { Family, twin, } \\
\text { and adoption } \\
\text { studies }\end{array}$ & Statistical & $\begin{array}{l}\text { To explore the } \\
\text { nature and mode } \\
\text { of action of genetic } \\
\text { risk factors }\end{array}$ \\
\hline 3. Gene finding & $\begin{array}{l}\text { High-density } \\
\text { families, trios, } \\
\text { case-control } \\
\text { samples }\end{array}$ & Statistical & $\begin{array}{l}\text { To determine the } \\
\text { genomic location } \\
\text { and identity of } \\
\text { susceptibility genes }\end{array}$ \\
\hline $\begin{array}{l}\text { 4. Molecular } \\
\text { genetics }\end{array}$ & Individuals & Biological & $\begin{array}{l}\text { To identify critical } \\
\text { DNA variants and } \\
\text { trace the biological } \\
\text { pathways from } \\
\text { DNA to disorder }\end{array}$ \\
\hline
\end{tabular}




\section{A Few Facts}

- Broad picture -

- Estimates of heritability of common psychiatric disorders 


\section{Heritability Of Psychiatric Disorders}

\section{Heritability Psychiatric Disorders Other Important Familial Traits}

\begin{tabular}{|c|c|c|}
\hline zero & & $\begin{array}{l}\text { Language } \\
\text { Religion }\end{array}$ \\
\hline $20-40 \%$ & $\begin{array}{l}\text { Anxiety disorders } \\
\text { Depression } \\
\text { Bulimia }\end{array}$ & $\begin{array}{l}\text { Myocardial Infarction } \\
\text { Personality }\end{array}$ \\
\hline $40-60 \%$ & $\begin{array}{l}\text { Alcohol and drug } \\
\text { dependence }\end{array}$ & $\begin{array}{l}\text { Blood Pressure } \\
\text { Plasma cholesterol } \\
\text { Adult-onset diabetes }\end{array}$ \\
\hline $60-80 \%$ & $\begin{array}{l}\text { Schizophrenia } \\
\text { Bipolar Illness }\end{array}$ & Weight \\
\hline $80-100 \%$ & Autism & Height \\
\hline
\end{tabular}




\section{Basic Genetic Epidemiology}

- For disorder that have been examined in multiple samples - e.g. schizophrenia, depression, alcohol dependence - general sense of replication is pretty good.

- No study perfect.

- Biases hard to rule out but unlikely to be very large.

- Good agreement across methods - esp for schizophrenia and alcoholism. 


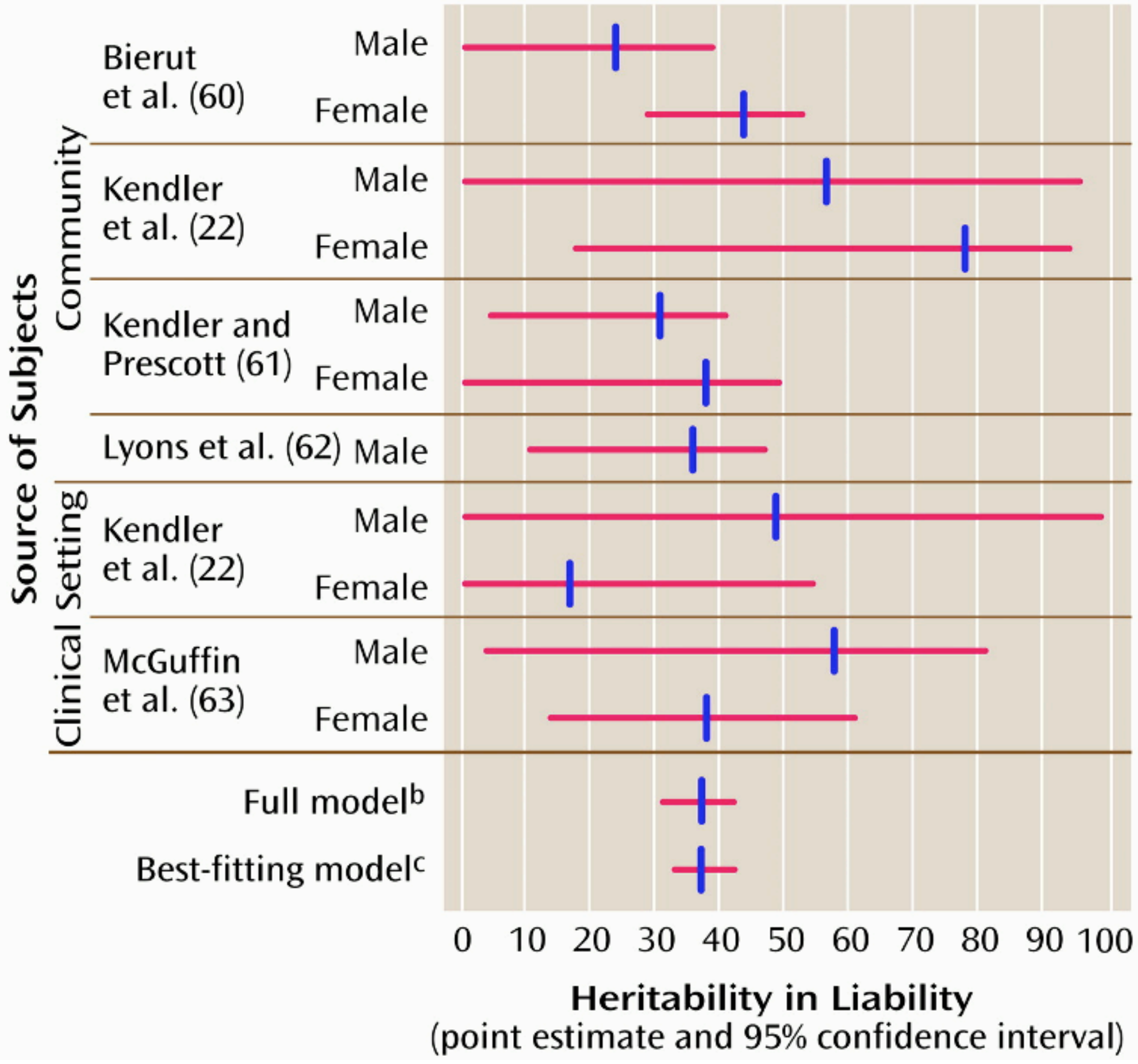




\section{Recent New Twin Study with Pederson and Colleagues}

Personal Interviews with 42,161 and 15,493 complete pairs from Swedish Twin Registry.

- Sample larger than all prior studies combined.

-When parameters constrained to be equal across sexes, heritability of lifetime MD estimated at 0.38 .

- Very similar to that estimated from the metaanalysis. 


\section{Gene Finding Methods}

- Picture entirely different.

- Replication rates low - for many years, was not clear if the literature was entirely noise.

- A few replicated genes - evidence that effect size is pretty small. 


\section{Published Genome Scans Of Schizophrenia}

\begin{tabular}{lcccl}
\hline Year & 1st Author & \# Markers & \# Families & Positive Regions At $p<.01$ \\
\hline 1994 & Coon & 329 & 9 & $4 p, 22 q$ \\
1995 & Moses & 413 & 5 & $2 p q^{* *}, 4 q, 9 q, 12 q, 14 q, 20 p$ \\
1998 & Levinson & 310 & 43 & $2 q, 10 q$ \\
1998 & Faraone & 459 & 43 & $10 p^{* *}$ \\
1998 & Kaufman & 459 & 30 & none \\
1998 & Coon & 406 & 1 & $2 p^{* *}$ \\
1998 & Blovin & 452 & 54 & $7 q, 8 p^{* *}, 13 q^{* *}, 14 q, 22 q$ \\
1999 & Williams & 229 & 196 & $4 p, 18 q, X c e n t$ \\
1999 & Hovatta & 351 & $1 / 20$ & $1 q 32^{* *}, 4 q^{* *}, 9 q$ \\
2000 & Schwab & 463 & 71 & $6 p^{* *}, 10 p^{* *}$ \\
2000 & Brzustowkicz & 381 & 22 & $1 q 2^{* *}, 8 p, 13 q$ \\
2001 & Gurling & 365 & 13 & $1 q 33^{* *}, 5 q^{* *}, 8 p^{* *}, 11 q^{* *}$ \\
2001 & Staber* & 356 & 12 & $15 q^{* *}, 22 q$ \\
2002 & Straub & 650 & 270 & $2 p q, 4 p, 5 q^{* *}, 6 p^{* *}, 8 p^{* *}, 10 p$ \\
2002 & DeLisi & 396 & 382 & $2 p q, 3 q, 10 p^{* *}, 3 q, 12 q, 22 q$ \\
2002 & DeLisi (CR) & 404 & 95 & $1 p, 5 q, 14 p$ \\
2002 & Stefansson & 950 & 33 & $8 p^{* *}$ \\
2002 & Devlin & $\sim 330$ & 5 & $5 q^{* *}, 2 p$ \\
2003 & Fallin & 382 & 29 & $1 p, 6 p, 10 q^{* *}$ \\
$\dot{*} P<.001$. & & & \\
\hline
\end{tabular}


RESULTS OF META-ANALYSES OF ASSOCIATION STUDIES BETWEEN INDIVIDUAL GENES AND PSYCHIATRIC DISORDERS PUBLISHED SINCE 2000

$\begin{array}{lll}\text { Disorder/Reference } & \text { Gene/Marker } & \text { OR } \\ \text { Schizophrenia }\{4610\} & \text { DRD3 S9G (SS) } & 1.13 \\ \text { Schizophrenia }\{4610\} & \text { 5HT2RA 102 T/C } & 1.07 \\ \text { Bulimia }\{4616\} & \text { 5HT2RA } 1438 \text { G/A } & 1.33 \\ \text { Anorexia Nervosa }\{4616\} & \text { 5HT2RA } 1438 \text { G/A } & 1.42 \\ \text { Schizophrenia }\{5092\} & \text { DRD2 Ser311Cys } & 1.43 \\ \text { Bipolar IIIness }\{5067\} & \text { 5HTT 44 bp insertion } & 1.14 \\ \text { Bipolar IIIness }\{5067\} & \text { 5HTT intron 2 VNTR polymorphism } & 1.18 \\ \text { ADHD }\{5073\} & \text { DRD5 dinucleotide repeat polymorphism } & 1.57 \\ \text { ADHD }\{5073\} & \text { DAT1 40 bp VNTR polymorphism } & 1.27 \\ \text { ADHD }\{5073\} & \text { DRD4 48 bp VNTR polymorphism } & 1.41\end{array}$

ADHD - attention deficit hyperactivity disorder bp - base pair

VNTR - variable number of tandem repeates

DR - dopamine receptor number

$5 \mathrm{HTTT}$ - serotonin transporter

DAT - dopamine transporter

$5 \mathrm{HT} 2 \mathrm{RA}$ - serotonin $2 \mathrm{~A}$ receptor 


\section{What is Special About Behavioral and Psychiatric Disorders?}

-Why do people become much more concerned in learning about possible genetic influences on personality or risk for depression than hearing that genes influence risk for cancer, atherosclerosis or asthma? 


\section{What is Special About Behavioral and Psychiatric Disorders?}

- At least part of the issue relates to our concept of self.

- I can have cancer, allergies or hypertension but these diseases do not directly impact my sense of self.

- But - my personality? That is me.

- I have allergies not I am allergies.

- I am introverted not I have introversion.

- Am I schizophrenic or do I have schizophrenia? 


\section{What is Special About Behavioral and Psychiatric Disorders?}

- Important element of folk psychology evidence in young children - that the world can be divided into objects with and without agency.

- Also, all of us - "closet Cartesians" have a deep tendency to associate agency with responsibility.

- We want to explain intentional events in psychological terms (e.g. self-agency and responsibility) while non-intentional events are seen to follow physical laws and to lack agency and responsibility. 


\section{What is Special About Behavioral and Psychiatric Disorders?}

- Finding that genes - which come from the physical world - hunks of DNA that make protein that has no intention or responsibility

- can impact on behavior - which is understood psychologically - causes us cognitive dissonance. It does not fit into our folk ideas of how the world ought to work. Hence, it makes us uncomfortable. 


\section{What is Special About Behavioral and Psychiatric Disorders?}

- So genetic research on for behavioral and psychiatric traits cut closer to the bone - in showing that genes can impact on traits related to our core sense of self. These results can challenge our sense of who we are and what makes us the way we are. From our religious and cultural background, we almost all have some sense of what we think it means to be human. Often this does not include the concept that some core parts of what we see as our self are influenced by our genes. 


\section{Behavioral/Psychiatric Genetics and Moral Responsibility}

- Shortly after publishing a major report that provided for the first time strong evidence that alcohol dependence in women was substantially influenced by genetic factors, I received a letter which said in part

- "How dare you give my Aunt Diana yet another excuse to say that her drinking is not her fault!" 


\section{Behavioral/Psychiatric Genetics and Moral Responsibility}

- Can only touch on this very complex but important topic.

- Deep sense in the public that "genes are destiny" but "environment is flexible."

- How to understand the relationship between genetic risk and volition.

- Genes don't force you to pick up a glass of beer and drink it.

- Do genes reflect extenuating circumstances or diminished capacity like passion or mental retardation? 


\section{Behavioral/Psychiatric Genetics and Parental Responsibility}

- I often speak of my research to NAMI groups - many parents of individuals with schizophrenia in the audience.

- Deeply moving to see them struggle with these research findings

- "It is better than being blamed for having raised him poorly."

- "But why did she get the bad genes and not my 3 other healthy children. Is that fair?"

- "I look at him, suffering with his illness and think about my DNA. How could I and my husband do this to him?"

- Hard to give answers to these questions. 